\title{
III
}

Imposto sôbre o capital particular empregado em empréstimo. Está sujeito a êle o credor domiciliado e residente no estrangeiro. Pode, entretanto, o fisco estadoal exigir o pagamento do devedor, si êste no contrato de empréstimo, assumiu o encargo de pagar os impostos federais, estaduais e municipais

Estevam de Almeida

1) Com a firma comercial de New York, Ladenburg, Thalmann \& Co., representada pela "Banque Française et Italienne pour l'Amérique du Sud", contratou a Companhia Paulista de Estradas de Ferro um empréstimo de 4.000.000 de dólares, ou sejam 29.460:000\$000, contrato lavrado em 17 de abril p. passado, nas notas do $90^{\circ}$ tabelionato desta Capital. A Recebedoria de Rendas de S. Paulo, pedindo instruções sôbre a arrecadação do imposto que lhe parecia devido, foi-lhe determinado que procedesse à arrecadação.

Como, nos termos da cláusula décima primeira, obrigou-se a Companhia Paulista a pagar todos os impostos brasileiros, federais, estaduais e municipais, foi esta intimada a efetuar o pagamento, tendo então recorrido ao dr. Secre- 
tário da Fazenda contra o lançamento e conseqüente intimação. Nestas palavras fundamentou ela o seu recurso:

"Emitido o empréstimo no estrangeiro, por intermédio de firma com domicílio jurídico no estrangeiro, e tomados os respectivos titulos por portadores estrangeiros, evidentemente Ladenburg, Thalman \& Co. não estão obrigados ao pagamento de semelhante tributo e muito menos a Companhia Paulista de Estradas de Ferro".

Pergunta-se: - tem procedência esta argüição?

\section{RESPONDO :}

2) A lei estadual n. 920 de 4 de agosto de 1904 criou o imposto sôbre o capital, discriminando-o em diferentes espécies, segundo o assento ou matéria sôbre que recái: propriedade imóvel rural, capital das casas de comércio, das emprêsas industriais e das sociedades anônimas e capital particular empregado em empréstimos.

O imposto sôbre o capital particular, determina a lei, é o que recái sôbre toda e qualquer quantia empregada em empréstimo. E êste é, na definição de A. WAHL, "Droit Fiscal", "l'opération par laquelle l'assujetti se procure des fonds, dont il doit rembourser le montant".

3) Esse, como qualquer imposto, é um tributo geral obrigatório e compreensivo em sua incidência (sujeito passivo) não sòmente dos cidadãos súbditos de um país, como também de quantos se põem sob a ação do poder constitutivo dêle. Acodem a pelo estas palavras de Rui Barbosa citadas pela própria recorrente: "Se ao estrangeiro não se permite negar subordinação às leis de outros paises, é tão sòmente enquanto neles estiver, a respeito dos atos que neles praticar ou que neles se destinarem a ter execução, e dos haveres que neles possuir" 
4) A citada lei $n .^{\circ} 920$, regulamentada pelo Decr. $.^{\circ} .^{\circ}$ 1251 de 12 de novembro de 1904 , no art. ${ }^{\circ} 59$, adotou a cobrança de imposto sôbre capital, por semestres, isto é, em abril e outubro de cada ano ou exercício. Mas a essa regra da cobrança por semestre abriu uma exceção o art. $^{\circ} 16$ letra d) da lei n. ${ }^{\circ} 894$ de 29 de dezembro de 1905:

"Os empréstimos particulares, quando o credor residir fora dêste Estado, pagarão a taxa de $5 \%$, de uma só vez, no alto da escritura, se for esta lavrada neste Estado; nos mais casos, quando o título ou escritura for apresentado a protesto, registo ou outra diligência, em que tenha de intervir oficial público do Estado"

5) Portanto, como claramente se vê, a lei criou o imposto sôbre capital aplicado em empréstimos, a incidir sôbre a mutuante residente no Estado ou fora dêle; tanto assim, repita-se, que, referindo-se ao mutuante domiciliado fora do Estado, aprouve-lhe modificar o modo ordinário de cobrança, por semestres, mandando que nesse caso seja feita de uma vez, isto é, por exercícios integrais.

Ora, por intermédio de um banco, realizou-se no Estado o empréstimo constante da escritura supra-referida, no qual se obrigou a Companhia mutuária a emitir determinada soma de obrigações ao portador, no total do empréstimo, e a firma Ladenburg, Thalmann \& Co. logo comprou toda a emissão, ao tipo de $90 \%$ líquido, para os revender lucrando a diferença. Está, pois, perfeitamente carateri.. zado um empréstimo feito no Estado por credores residentes fora dêle.

6) A previsão de impostos a pagar está expressa no contrato de 17 de abril, na clausula 11-a., em que a mutuária assumiu a responsabilidade pelo pagamento dos impostos federais, estaduais ou municipais. Por esta delegação passiva, solenemente aceita pela Companhia Paulista, ela 
assumiu a responsabilidade pelos impostos como si próprios, e pela lei o simples fiador é sujeito passivo da cobrança de impostos.

Contra a Companhia, pois, cabe iniciar-se a competente executiva.

7) Neste Estado, já foi discutido o pagamento do imposto sôbre o capital empregado em empréstimos particulares, por credor domiciliado no estrangeiro. Mas nem sequer dúvida suscitou-se sôbre ser ou não devido tal imposto. O que suscitou dúvida, julgada procedente, foi a interpretação das expressões "de uma só vez" da citada lei n. ${ }^{\circ} 894$.

Entendia a Fazenda que essas expressões autorizavamna a cobrar, de uma só vez, ou por junto, o imposto sôbre o capital em todo o periodo em que devia durar o empréstimo. A decisão foi contrária à Fazenda, considerada ilegal a cobrança de impostos futuros, pois que o empréstimo contraído a longo prazo pode extinguir-se por muitos modos antes de terminado o prazo, assim como impostos existentes na ocasião em que o empréstimo foi contraído podem desaparecer nos anos seguintes, ser aumentados ou diminuídos.

Na "Revista dos Tribunais", vol. XXIX, pag. 647 lê-se êste julgado, assim como as sensatas ponderações da lavra do dr. Azevedo Marques, firmando a interpretação das expressões "de uma só vez", como significativas de que a cobrança de imposto, quando o credor tem domicílio fora do Estado, divergem do em que o devedor é domiciliado no Estado, em se fazer esta semestralmente e aquela "de uma só vez, cada ano"

Aceita esta inteligência, a cobrança que a Recebedoria tem de promover em 1922, repetir-se-á anualmente, enquanto durar o empréstimo e vigorar o imposto. 